Sains Malaysiana 50(2)(2021): 461-473

http://dx.doi.org/10.17576/jsm-2021-5002-17

\title{
Aqueous Polyphenol Semi-Purified Fractions from Galls of Quercus infectoria Increase ALP Activity and Mineralisation of hFOB 1.19 Cells
}

(Fraksi Separa Tulen Polifenol Akueus daripada Puru Quercus infectoria Meningkatkan Aktiviti ALP dan Pemineralan Sel hFOB 1.19)

\author{
Hermizi Hapidin*, FairuZa Munirah MaZlan, Hasmah Abdullah \& Ima NiRWAna Soelaiman
}

\begin{abstract}
The galls of Quercus infectoria (QI) have been reported to possess numerous medicinal values and give a positive effect on bone metabolism. This study investigated the effects of semi-purified fractions of QI gall extract on the proliferation, alkaline phosphatase (ALP) activity, and mineralisation of human foetal osteoblast cell line ( $h F O B$ 1.19). The semi-purified fractions (fraction $A$ and $B$ ) were prepared by column chromatography methods. MTT assay was used to measure cell proliferation activity to obtain half maximal concentration $\left(E C_{50}\right)$ of the cells treated with fraction A (phenolic components and contained amide), fraction B (phenolic components with the presence of alkene), and pamidronate (drug control). The most potent or lowest $E C_{50}$ was further used to measure ALP activity in the treated and untreated cells at day 1, 3, 7, 10, and 14 by ELISA. Cell mineralisation was determined by von Kossa staining for phosphate depositions and Alizarin Red S staining for calcium depositions. The $E C_{50}$ values for fraction $A$ and $B$ were 8.86 and $9.92 \mu \mathrm{g} / \mathrm{mL}$, respectively, which showed a greater effect compared to the pamidronate $(15.27 \mu \mathrm{g} / \mathrm{mL})$. The ALP activity of both fractions in the treated cells were also greater compared to the two control groups (cells treated with pamidronate and untreated cells), starting from day 3 onwards. The calcium depositions appeared as red spots, while phosphate depositions appeared as black spots. Interestingly, the calcium depositions of cells treated with both fractions were higher than those of the two control groups. In conclusion, semi-purified fractions of QI gall extract enhanced proliferation, improved mineralisation, and increased ALP activity of hFOB 1.19 cells.
\end{abstract}

Keywords: Alizarin Red S; alkaline phosphatase (ALP); hFOB 1.19 cell line; Quercus infectoria; von Kossa

ABSTRAK

Puru Quercus infectoria (QI) telah dilaporkan mempunyai nilai perubatan yang banyak dan memberi kesan positif pada metabolisme tulang. Penyelidikan ini dijalankan untuk mengkaji kesan fraksi separa tulen QI pada proliferasi, aktiviti alkalin fosfatase (ALP) dan pemineralan sel osteoblas fetal manusia (hFOB 1.19). Fraksi separa tulen QI (fraksi A dan B) telah disediakan melalui kaedah kromatografi kolum. Asai MTT digunakan untuk mengukur aktiviti proliferasi sel bagi menentukan kepekatan separa maksimum $\left(E C_{50}\right)$ sel yang dirawat dengan fraksi A (komponen fenolik dan mengandungi amida), fraksi B (komponen fenolik dengan kehadiran alkena) dan pamidronat. Nilai $E_{50}$ paling poten atau rendah yang diperoleh digunakan untuk mengukur aktiviti ALP dalam sel yang dirawat dan juga sel yang tidak dirawat pada hari 1, 3, 7, 10 dan 14 melalui ujian ELISA. Pemineralan sel ditentukan dengan pewarnaan von Kossa bagi pemendapan fosfat dan pewarnaan Alizarin Red S bagi pemendapan kalsium. Nilai EC $C_{50}$ bagi sel yang dirawat dengan fraksi A fraksi B masing-masing adalah 8.86 dan $9.92 \mu \mathrm{g} / \mathrm{mL}$ yang menunjukkan kesan lebih hebat berbanding pamidronat (15.27 $\mu \mathrm{g} / \mathrm{mL})$. Kedua-dua fraksi juga menunjukkan aktiviti ALP yang lebih tinggi berbanding kedua-dua kumpulan kawalan (sel yang dirawat dengan pamidronat dan sel yang tidak dirawat), bermula pada hari ke-3 dan hari-hari berikutnya. Pemendapan kalsium kelihatan sebagai tompokan merah manakala pemendapan fosfat kelihatan tompokan hitam. Menariknya, pemendapan kalsium oleh sel yang dirawat dengan kedua-dua fraksi adalah lebih tinggi berbanding dua kumpulan kawalan. Kesimpulannya, fraksi separa tulen QI menambahkan proliferasi, memperbaiki pemineralan dan meningkatkan aktiviti ALP sel hFOB 1.19.

Kata kunci: Alizarin Red S; alkalin fosfatase (ALP); Quercus infectoria; sel hFOB 1.19; von Kossa 


\section{INTRODUCTION}

Osteoporosis is a skeletal disorder characterised by progressive loss of normal bone density with deterioration of bone microarchitecture. Osteoporosis increases the risk of fracture in a patient, which may become a major public health problem that is associated with age-related fractures (Sözen et al. 2017). In recent years, available treatments for osteoporosis have been designed to reduce bone loss or stimulate bone formation.

Types of osteoporosis treatment include dietary and lifestyle changes and pharmacological intervention. Examples of effective treatments that have been proven to cure osteoporosis are bisphosphonates, calcitonin, and selective oestrogen receptor modulators (SERMs) (Davidson 2003). However, long-term usage of those treatment modalities can induce adverse effects in most patients. For instance, hormone replacement therapy (HRT) has been shown to increase the risk of ovarian and breast cancer in patients (Humphries \& Sabrina Gill 2003; Zhou et al. 2008). This risk can become life-threatening if not managed properly.

Alternative medicine has become an option due to the long-term side effects caused by synthetic drug or modern medicine, although the advantages of modern medicine in curing health problems far exceed the disadvantages. Herbal remedies such as St. John's wort, Ginkgo biloba, Echinacea, garlic, saw palmetto, ginseng, goldenseal, aloe, Siberian ginseng, and valerian have been used among Americans for health maintenance (Mar \& Bent 1999). In Malaysia, Quercus infectoria (QI) or locally known as 'manjakani' is one of the popular herbs used traditionally in postpartum care to restore the elasticity of the uterine wall (Muhamad \& Mustafa 1994).

The main phytochemicals found in QI galls are polyphenols such as tannin (50 to 70\%), gallic acid (2 to 4\%), and ellagic acid (Bruneton 1999). Polyphenols are a group of natural compounds with phenolic structural features and are strong antioxidants. Past studies have shown that different polyphenol subgroups may differ significantly in their stability, bioavailability, and effect on physiological functions (Tsao 2010). As reviewed by Habauzit and Horcajada (2008), polyphenols can affect bone metabolism. Osteoblast proliferation, differentiation, and mineralisation as well as osteoclast function may be modulated by polyphenols (Trzeciakiewicz et al. 2009).

Studies on modulation of cell function by polyphenols have been performed in different in vitro models such as cancer cells, epithelial cells, and skeletal cells (Fantini et al. 2015; Hurst et al. 2010; Noe et al. 2004; O'Prey et al. 2003; Vittal et al. 2004). Nevertheless, little is known regarding human osteoblastic cells. Bu et al. (2009) studied the influence of dried plum polyphenol extract on mouse calvarial preosteoblastic cells (MC3T3-E1) under normal and inflammatory conditions. They found that this extract was nontoxic for osteoblasts and was able to stimulate alkaline phosphatase (ALP) activity and mineralised nodule formation. Bone-specific ALP activity is associated with the bone formation rate in metabolic disease of the bone and during normal physiological bone growth (Gundberg 1993). In addition, Vester et al. (2014) showed that the incubation of human primary osteoblasts with green tea extract (containing more than $80 \%$ polyphenols) significantly reduced oxidative stress and improved cell viability. In our previous study, the combination of osteoporotic drug (pamidronate) and semi-purified fractions of QI (QIsmF) with $\mathrm{EC}_{50}$ of 11.60 $\mu \mathrm{g} / \mathrm{mL}$ showed positive effects on the proliferation and differentiation of osteoblasts (Raudhah et al. 2018).

The aqueous crude extract of QI enhanced cell proliferation and increased bone formation markers (ALP and osteocalcin) (Hapidin et al. 2015). However, as QI extracts contain a combination of numerous types of bioactive compounds or phytochemicals (Sasidharan et al. 2011), it is difficult to determine which specific compounds or fractions of the extract that produce the most potent effects towards osteoblasts. Hence, in this study, the semi-purified polyphenol fractions of QI gall extract were obtained via chromatography techniques. Then, the effects of the selected semi-purified fractions (fraction A and B) on the proliferative activity were measured using enzyme-linked immunosorbent assay (ELISA), as well as mineralisation of a human foetal osteoblast cell line (hFOB 1.19 cells), which was observed using an inverted microscope and histochemical staining.

\section{MATERIALS AND METHODS}

\section{PREPARATION OF Quercus infectoria GALLS EXTRACT}

Quercus infectoria (QI) galls were bought from a Chinese traditional medicine store in Kota Bharu, Kelantan. The galls were identified based on their morphology such as external colour, size, surface, texture, odour, taste, and thickness (Asif et al. 2012). The plant identification was then certified by Assoc. Prof. Dr. Hasmah Abdullah, an experienced plant researcher at the School of Health Sciences, Universiti Sains Malaysia (USM). The specimen (QI012012) was deposited in the Biomedicine Laboratory, School of Health Sciences, USM.

QI gall extract was prepared according to our previous procedures, with some modifications (Hapidin et al. 2015). QI galls were crushed by using a pestle and mortar into small pieces, then ground into powder form 
using an electronic grinder. QI powder was then extracted using distilled water by refluxing at $50{ }^{\circ} \mathrm{C}$ for $24 \mathrm{~h}$. After that, the extract obtained was filtered using a Whatman No. 1 filter paper (GE Healthcare, UK) and concentrated by using a rotary evaporator (Heidolph Rotavac, Germany). The aqueous QI gall extract was further lyophilised in a freeze drier until powdery in form and stored at $-20{ }^{\circ} \mathrm{C}$ for future usage.

PRODUCTION OF SEMI-PURIFIED Quercus infectoria POLYPHENOLS BY USING COLUMN CHROMATOGRAPHY

Flash column chromatography was performed on silica gel $60,0.063-0.200 \mathrm{~mm}, 60 \AA$ pore size, $\mathrm{pH} 6.5-7.5$ in glass columns sized $40 \mathrm{~mm}$ in width and $500 \mathrm{~mm}$ in length. Silica gel was supplied by Merck, Millipore. Flash columns were manually packed using a layer of cotton plug and the slurry method. Cotton plug was transferred into the column for retention of adsorbent, followed by a transfer of $150 \mathrm{~g}$ silica gel in mobile phase solvents; acetonitrile:methanol:water (75:25:5). The sample was loaded with a Pasteur pipette directly to the head of the column before elution by dissolving $5 \mathrm{~g}$ of QI in $50 \mathrm{~mL}$ of $70 \%$ ethanol. The mobile phase solvent was continuously added as the final layer simultaneously with the elution process until fraction collection was accomplished. The fractions were collected in test tubes, graduated with the fraction volume, and visualised by spotting on thin layer chromatography (TLC) plates. The fractions collected were labelled fraction A and fraction B.

FOURIER-TRANSFORM INFRARED SPECTROSCOPY (FTIR) ANALYSIS OF FRACTION A AND B

Fourier-transform infrared spectroscopy (FTIR) is a reliable and sensitive method for detection and identification of functional groups present in both fractions (Eberhardt et al. 2007; Hazra et al. 2007). In addition, it is widely used because of its simplicity, cost effectiveness, and rapidness in detecting phytocomponents (Aysal et al. 2007; Ibrahim \& Abd-El-Aal 2008; Lieber et al. 1999). The efficiencies of herbal medicines depend on the amounts of active components, which could vary significantly in their contents.

Fractions A and B were scanned in the wavelength range of 600-5000 nm using Bruker Tensor 27 Spectrophotometer (USA). FTIR analysis was performed using OPUS data collection program, which was used to detect the characteristic peaks and record the values of FTIR. Each analysis was repeated twice for spectrum confirmation. The FTIR spectrum was used to identify the functional groups of the active components based on the peak value in the region of infrared radiation.

\section{CELL CULTURE}

Cell Revival and Subculture

Human foetal osteoblast cell line hFOB 1.19 (CRL-11372) was purchased from ATCC (American Type Cell Culture) (Manassas, VA 20110, USA). The hFOB 1.19 cells at passage 16 was cultured in Dulbecco's Modified Eagle Medium F-12 nutrient mixture (DMEM/F12) (Invitrogen GmBH, Karlsruhe, Germany), which was supplemented with $10 \%$ foetal bovine serum (FBS) (Invitrogen $\mathrm{GmBH}$, Karlsruhe, Germany) and 1\% penicillin/streptomycin serum (Invitrogen GmBH, Karlsruhe, Germany) (standard medium). The cells were incubated in $5 \% \mathrm{CO}_{2}$ $37^{\circ} \mathrm{C}$ humidified incubator (Sheldon, US) and monitored closely for $24 \mathrm{~h}$. All procedures were carried out in an aseptic condition.

\section{Cell Treatment}

Fraction A and B were diluted in dimethyl sulfoxide (DMSO) (Nacalai Tesque, Japan). Pamidronate (Toronto Research Chemicals, Canada) was used as a control drug, whereas the cells treated only with complete medium were used as the negative control. The treated cells were incubated for $72 \mathrm{~h}$ in the $37{ }^{\circ} \mathrm{C}$ humidified incubator supplemented with $5 \% \mathrm{CO}_{2}$. The tests were conducted in triplicate and repeated for three independent times. All culturing work was handled using sterile techniques and done in Biosafety Cabinet Class II.

\section{CELL VIABILITY AND HALF MAXIMAL EFFECTIVE CONCENTRATION $\left(\mathrm{EC}_{50}\right)$ DETERMINATION}

3-(4,5-Dimethyl-2-thiazolyl)-2,5-diphenyl-2Htetrazolium bromide (MTT) assay (Nacalai Tesque, Japan) was performed to determine cell viability. Cell culture with more than $80 \%$ confluency was used and, in this test, yellow MTT was reduced to a purple formazan. MTT (5 mg) was measured using an electronic weighing balance and completely dissolved in $1 \mathrm{~mL}$ of Dulbecco's Phosphate-Buffered Saline (PBS) (ThermoFisher Scientific, USA). Then, $15 \mu \mathrm{L}$ of freshly prepared MTT dye (Nacalai Tesque, Japan) was added to each well, and the mixture was further incubated for $4 \mathrm{~h}$ (Putnam et al. 2007).

After the supernatant was removed, $100 \mu \mathrm{L}$ DMSO was added to all wells to solubilise the formazan crystals formed, and the plate was further incubated for $15 \mathrm{~min}$. Then, absorbance (A) was measured at $570 \mathrm{~nm}$ using a microplate reader (Tecan Infinite M200, Switzerland) (Hassan et al. 2015). The intensity of the wavelength absorbed was proportional to the percentage of viable 
cells present in the wells. The percentage of viable cells was calculated by using the following formula:

Percentage of viable cells $=($ OD Sample $) /($ OD Control $)$ $\times 100 \%$

where OD Sample is the optical density of treated samples; OD Control is the optical density of the control.

\section{PROLIFERATION ASSAY}

The proliferation assay was done to determine the number of hFOB 1.19 cells treated with pamidronate, fraction A and $\mathrm{B}$ at days $1,3,7,10$, and 14 . The cells were plated at $5 \times 10^{3}$ cells/well with a $100 \mathrm{uL}$ culture medium per well in a 96-well microtiter plate and left overnight prior to attachment. Pamidronate, fraction $\mathrm{A}$, and fraction $\mathrm{B}$ were added into each well at different concentrations, and the plate was incubated at $5 \% \mathrm{CO}_{2}$ in a $37{ }^{\circ} \mathrm{C}$ humidified incubator. The cells were trypsinised with $100 \mathrm{uL}$ trypsin/ EDTA and incubated for $3 \mathrm{~min}$ for the cells to detach. Then, an inverted microscope was used to view the cells and confirm that $90 \%$ detachment had occurred. To stop the trypsinisation process, $200 \mathrm{uL}$ of culture medium was added, and the mixture was resuspended. Automated cell counting was carried out using Countess Automated Cell Counter (Invitrogen, USA), and the number of viable cells versus time for each treatment and control groups were plotted in a dose-response curve and analysed.

\section{QUANTIFICATION OF ALP ACTIVITY IN MEDIUM BY}

ENZYME-LINKED IMMUNOSORBENT ASSAY (ELISA)

The alkaline phosphatase (ALP) activity of hFOB 1.19 treated with fraction $\mathrm{A}$, fraction $\mathrm{B}$, and pamidronate was detected through the hydrolysis of $p$-nitrophenyl phosphate (substrate) into $p$-nitrophenol at $37^{\circ} \mathrm{C}$ with $\mathrm{pH}$ 10.3. This was achieved by using the ALP ELISA test kit (Randox, UK). The cells were plated in a 96-well microtiter plate at $5 \times 10^{3}$ cells/well with $115 \mu \mathrm{L}$ of culture medium per well. After $24 \mathrm{~h}$, the cells were treated with the QI gall extract fractions and pamidronate. Then, the treated cells were incubated for $1,3,7,10$, and 14 days in $37{ }^{\circ} \mathrm{C}$ humidified incubator supplemented with $5 \% \mathrm{CO}_{2}$. ALP activity was measured using the ELISA plate reader (VersaMax, US) at $405 \mathrm{~nm}$.

\section{HISTOCHEMICAL ASSAYS FOR MINERALISED CALCIUM PHOSPHATE DEPOSITS}

\section{Calcium staining}

The fixed cultures were covered with $1.0 \%$ Alizarin Red $S$ sodium solution $\left(0.028 \%\right.$ in $\left.\mathrm{NH}_{4} \mathrm{OH}\right)$ (Sigma-Aldrich, USA), $\mathrm{pH} 4.2$ for $20 \mathrm{~min}$ for calcium staining. The cultures were then rinsed with distilled water and acid ethanol (ethanol, $0.01 \% \mathrm{HCl}$ ) (McGee-Russell 1958). The calcium deposits were stained red and observed under an image analyser (Olympus, Japan).

\section{Phosphate staining}

von Kossa (Merck Millipore, USA) staining (McGeeRussell 1958) was used for phosphate deposit assessment. The fixed cultures were covered with $1.0 \%$ silver nitrate solution (Merck Millipore, USA) and kept for $1 \mathrm{~h}$ under UV light. After rinsing, 5.0\% sodium thiosulphate (Merck Millipore, USA) was added for $30 \mathrm{~min}$, and the culture was washed again. Phosphate deposits were stained black and the cultures were observed under an image analyser (Olympus, Japan)

\section{STATISTICAL ANALYSIS}

Results were expressed as mean \pm standard deviation (SD) of three independent experiments $(n=3)$. Data for cell viability and $\mathrm{EC}_{50}$ determination were analysed with a one-way ANOVA test by using the GraphPad Prism 6.0. In addition, data analyses for the results of proliferation activity and ALP activity were performed using the IBM Statistical Package of Social Sciences (SPSS) software, version 22. Shapiro-Wilk test was used for normality. The statistical significance of differences was determined using one-way ANOVA followed by Tukey HSD test as a post-hoc. The results were considered to be statistically significant for a $p$ value of $<0.05$.

\section{RESULTS AND DISCUSSION}

\section{FTIR SPECTROSCOPIC ANALYSIS OF FRACTION A AND} FRACTION B

In this study, semi-purified fractions of QI gall extract were obtained through separation by column chromatography for polyphenol extraction and removal of unwanted compounds. The semi-purified fraction is the crude extracts that have typically undergone further generic processing using solid phase extraction as a chemical filter to bias the screening profile (Avery et al. 2010). Figures 1 and 2 show the FTIR spectra for fraction A and B of QI gall extract, respectively. With reference to previous studies (Anand \& Gokulakrishnan 2012; Vignesh et al. 2015; Yamunadevi et al. 2012), the results of FTIR peak values and different functional groups in both fraction A and B are shown in Table 1. Twenty different functional groups were analysed, and the wavelengths ranged from 600 to $3800 \mathrm{~cm}^{-1}$. The commonly present functional groups in both fractions were alcohol or phenolic components, carboxylic acids, alkanes, and aromatic and alkyl halides. Fraction B showed the presence of alkene, but this 
was absent in fraction A. On the other hand, fraction A contained amide or amines; however, this was not found in fraction B (Table 1). According to the peak values obtained from FTIR spectra of both fractions, the broad band at $3000-3700 \mathrm{~cm}^{-1}$ belongs to the stretching vibration of a phenolic hydroxyl group $(-\mathrm{OH})$, which represents hydrogen bonding (Anand \& Gokulakrishnan 2012; Naz et al. 2014; Pantoja-Castro \& Gonzalez-Rodriguez 2012). Hence, both fractions of QI were found to contain the functional group of total phenolic content expressed mainly as tannin and gallic acid, ranging from $3300-3650 \mathrm{~cm}^{-1}$.

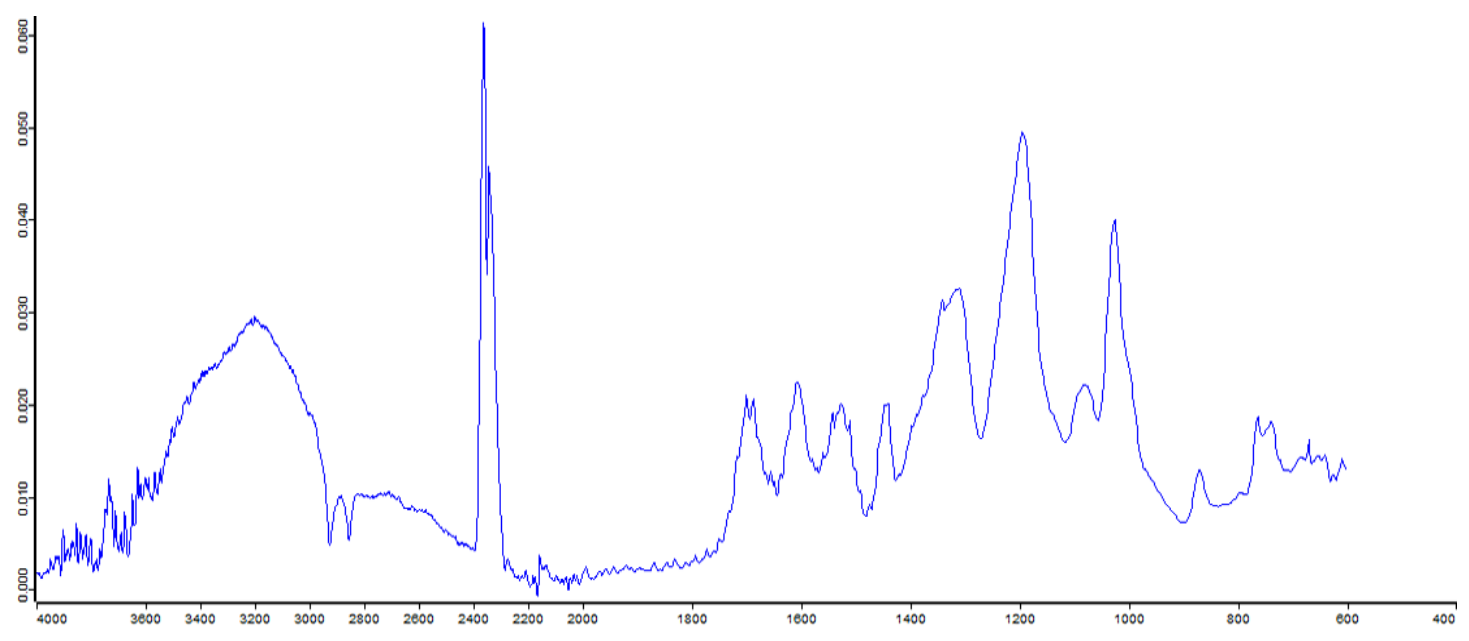

Wavenumbers $\mathrm{cm}^{-1}$

FIGURE 1. FTIR Spectrum profile of fraction A

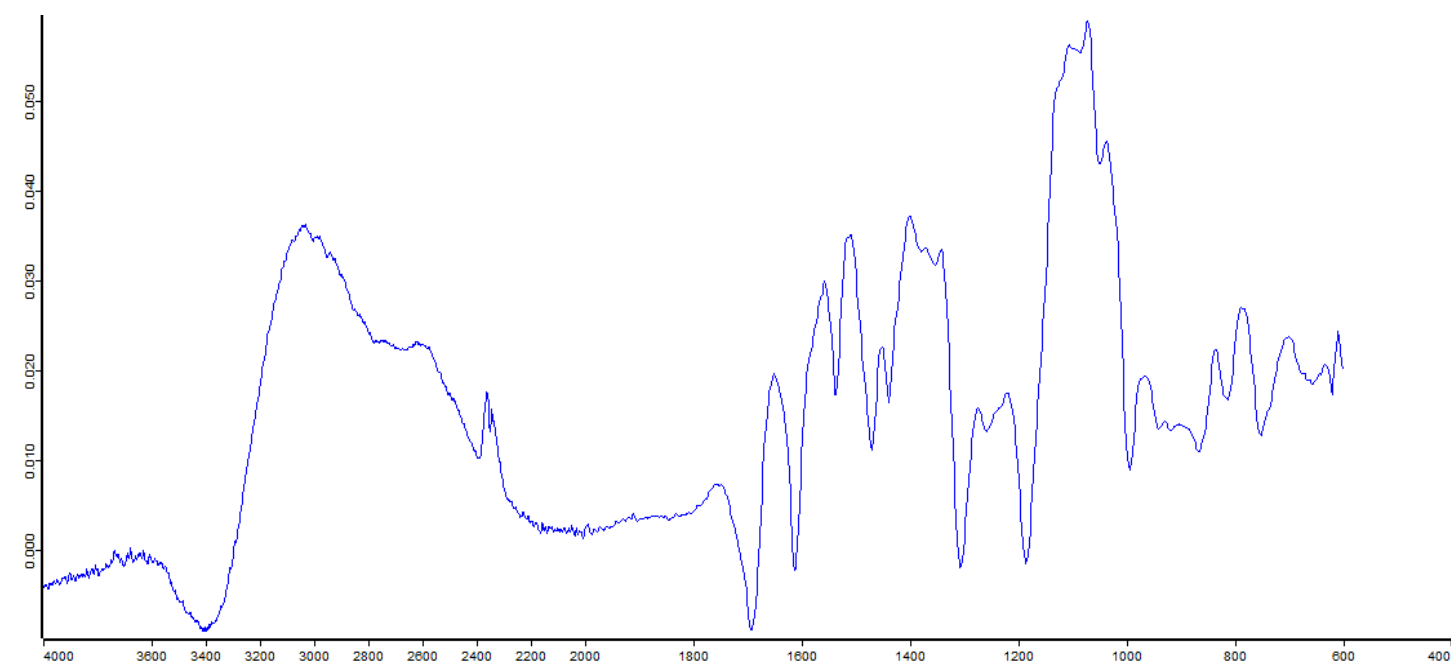

Wavenumbers $\mathrm{cm}^{-1}$

FIGURE 2. FTIR Spectrum profile of fraction B 
TABLE 1. FTIR peak values and different functional groups in fraction A and B

\begin{tabular}{|c|c|c|}
\hline \multicolumn{2}{|c|}{ Peak value $\left(\mathrm{cm}^{-1}\right)$} & \multirow[t]{2}{*}{ Functional groups } \\
\hline Fraction A & Fraction B & \\
\hline 3749 & - & Unknown \\
\hline 3619 & 3590 & Alcohols/phenols \\
\hline 3313 & 3461 & Alcohols/phenols \\
\hline 3199 & - & Amide/amines \\
\hline- & 3067 & Unknown \\
\hline- & 3044 & Unknown \\
\hline 2884 & 2981 & Carboxylic acids \\
\hline 2361 & 2361 & Unknown \\
\hline 2342 & - & Unknown \\
\hline 1699 & - & Aromatic \\
\hline- & 1651 & Alkene \\
\hline 1606 & 1556 & Aromatic \\
\hline 1525 & 1512 & Aromatic \\
\hline 1440 & 1449 & Alkane/Aromatic \\
\hline 1310 & 1397 & Unknown \\
\hline- & 1340 & Unknown \\
\hline 1193 & 1215 & Alcohols \\
\hline 1080 & 1074 & Alcohols \\
\hline 1025 & 1033 & Alcohols \\
\hline $608-763$ & $607-786$ & Alkyl halide \\
\hline
\end{tabular}

HALF MAXIMAL EFFECTIVE CONCENTRATION $\left(\mathrm{EC}_{50}\right)$ OF Quercus infectoria SEMI-PURIFIED POLYPHENOLS AND PAMIDRONATE TREATMENTS FOR hFOB 1.19 CELLS

The $\mathrm{EC}_{50}$ value for fraction A was 8.86 and $9.62 \mu \mathrm{g} / \mathrm{mL}$ for fraction $\mathrm{B}$, whereas $\mathrm{EC}_{50}$ for pamidronate was 15.27 $\mu \mathrm{g} / \mathrm{mL}$ (Figure 3 ). The fraction A and B of QI galls were more effective compared to pamidronate, since their $\mathrm{EC}_{50}$ values were lesser. This indicates that a lower concentration of semi-purified fractions of QI gall extract is required to enhance the proliferation of hFOB 1.19 cells compared to pamidronate, the control drug. 


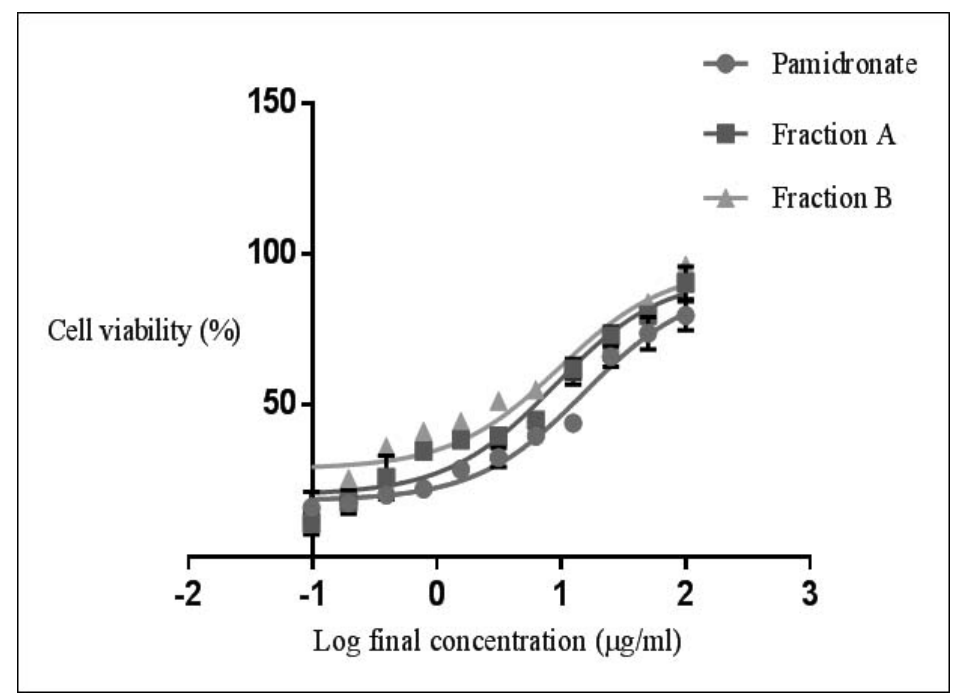

FIGURE 3. Cell viability of hFOB 1.19 treated with pamidronate and semipurified fractions of QI (fraction A and $\mathrm{B}$ ). $\mathrm{EC}_{50}$ values were calculated by using dose response stimulation curve in GraphPad Prism version 6.0 for Windows. The $\mathrm{EC}_{50}$ for fraction A was $8.86 \mu \mathrm{g} / \mathrm{mL}$ and fraction $\mathrm{B}$ was 9.62 $\mu \mathrm{g} / \mathrm{mL}$; both were lower than $\mathrm{EC}_{50}$ for pamidronate, $15.27 \mu \mathrm{g} / \mathrm{mL}$

\section{PROLIFERATION ASSAY OF HFOB 1.19 CELLS}

The $\mathrm{EC}_{50}$ values were then used in the treatment of hFOB 1.19 cells to observe the pattern of cell proliferation during 14 days of incubation. The graph of proliferation versus time shows that the hFOB 1.19 cell count in all four groups significantly increased with time (day 3 until day 14). Interestingly, from day 3 onwards, the numbers of hFOB 1.19 cells treated with both fractions were significantly higher compared to those from the other two control groups. In addition, starting on day 7 onwards, the hFOB 1.19 cells treated with fraction B were significantly higher in number compared to those treated with fraction $\mathrm{A}$ (Figure 4). Thus, fraction B was much greater in enhancing proliferation activity of hFOB 1.19 cells compared to fraction A.

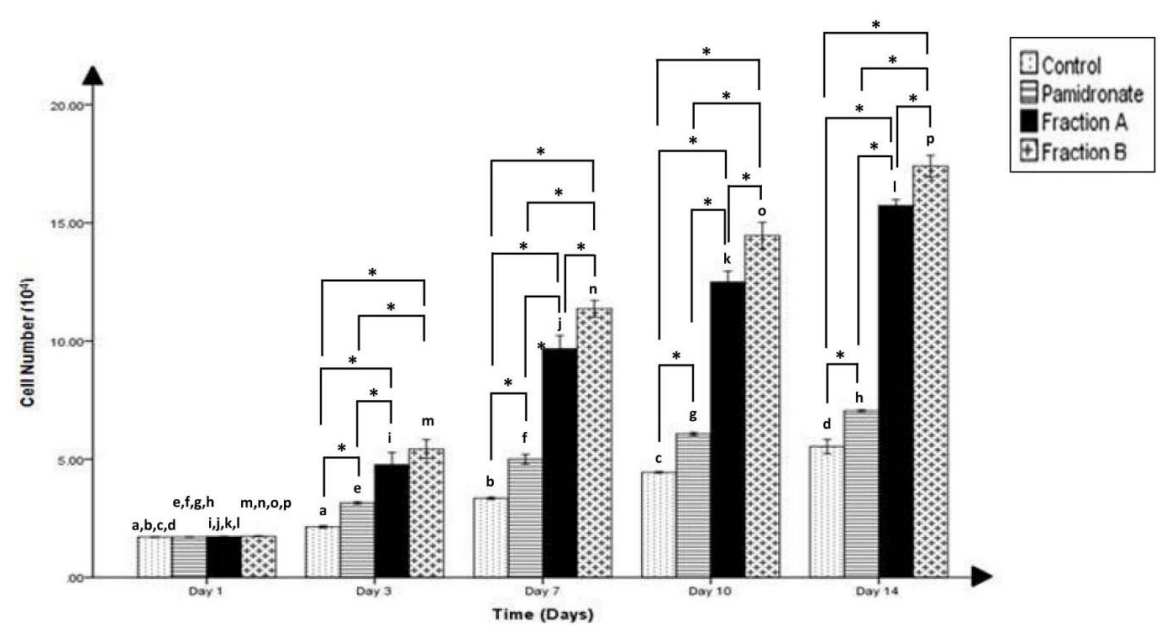

FIGURE 4. Cell number $\left(\times 10^{4}\right)$ after $1,3,7,10$, and 14 days of incubation. The values of the bars represented the mean \pm standard deviation (SD) of the four independent experiments. * Significant differences were detected between the four groups within the same day $(p<0.05)$ by one-way ANOVA and Tukey's test. Days that shared the same letter showed a significant difference (within the same group) $(p<0.05)$ by one-way ANOVA and Tukey's test 


\section{ALKALINE PHOSPHATASE (ALP) ACTIVITY OF HFOB 1.19 CELLS}

The alkaline phosphatase (ALP) activities of hFOB 1.19 cells in all four groups significantly increased with time, starting from day 3 until day 14. Figure 5 shows that from day 3 onwards, the ALP activities of hFOB 1.19 cells treated with both fractions were significantly higher compared to those from the other two control groups. However, fraction B treatment resulted in a more significant and higher ALP activity compared to fraction A treatment, starting on day 3 onwards. Moreover, on day 14, the ALP activity of hFOB 1.19 cells treated with semi-purified fractions of QI extract was the highest, especially for fraction B, compared to the ALP activities for the control cells and cells treated with pamidronate (Figure 5).

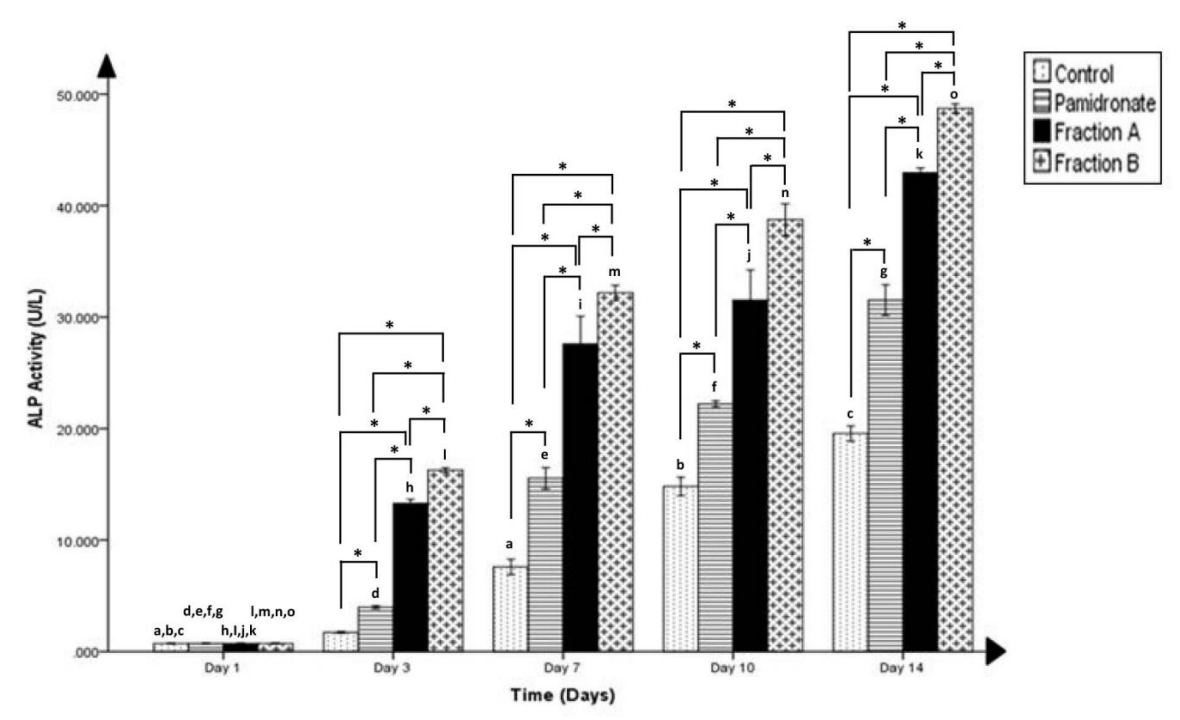

\begin{abstract}
FIGURE 5. ALP activity of hFOB 1.19 cells; untreated cells (control), cellstreated pamidronate, and cells-treated with semi-purified polyphenols of QI (Fractions A and B) after 1, 3, 7, 10, and 14 days of incubation. The values of the bars represented the mean \pm standard deviation (SD) of the four independent experiments. *Indicates significant difference between the four groups within the same day $(p<0.05)$ by one-way ANOVA and Tukey's test. Days that shared the same letter showed a significant difference (within the same group) $(p<0.05)$ by one-way ANOVA and Tukey's test
\end{abstract}

The increment of ALP activity during 14 days for all treatment groups proves the capability of all treatment vehicles, especially fractions A and B. The results obtained are consistent with a previous study where the ALP activity in hFOB/plasmid vector control cells significantly increased as a function of time in the cells and peaked on day 12 ( $\mathrm{Li}$ et al. 2006). Furthermore, ALP was upregulated and increased in the presence of semi-purified fractions of QI extract (fractions A and B) just after $24 \mathrm{~h}$ and continued to increase twofold on day 7 of incubation. This condition is consistent with a previous study on pomegranate extract (PME) which possesses phenolic compounds, together with flavonoids, anthocyanins, and tannins, as the main group of antioxidant phytochemicals. The study found that PME $(80 \mu \mathrm{g} / \mathrm{mL})$ significantly increased the ALP activity of MC3T3-E1 osteoblast, supporting its suggested role in modulating osteoblastic cell differentiation (Sreekumar et al. 2014).

The ALP activities between both groups treated with semi-purified fractions of QI extract were also measured and compared. The upregulated activity of ALP might be induced by the presence of multifunctional groups in the fractions as shown by the FTIR spectra. Thus, the higher expression of ALP activity stimulated by fraction $\mathrm{B}$ is probably due to the presence of different types of functional groups of certain polyphenol compounds (e.g. carboxylic acid, alkene, and phenol group), which are 
more effective towards osteoblastic activity. Idris et al. (2009) concluded that biphenyl carboxylic acid derivatives like ABD350 have no significant inhibitory effects on osteoblast activity in vitro. Besides, phenols that contain carboxylic acid will form phenolic acid. Phenolic acids are the second largest subclass of polyphenols (Stipanuk \& Caudill 2013). Many studies have found that polyphenols demonstrate a positive effect on bone metabolism. As such, a polyphenolic phytoestrogen enhances proliferation and osteoblastic differentiation in human bone marrowderived mesenchymal stem cell (hBMSC) cultures via ER-dependent mechanism and coupling to extracellular signal-regulated kinase 1/2 (ERK1/2) activation (Dai et al. 2007). A study by Kowalczyk et al. (2012) concluded that five novel alkene-bridged analogues showed promising biological activity in a proliferation study in primary foetal rat osteoblasts at physiological concentrations. Besides, Garcia-Martinez et al. (2016) found that phenolic compounds and extracts from different varieties of extra virgin olive oil stimulate human osteoblast cell (MG-63) proliferation.
FORMATION OF MINERALISED CALCIUM AND PHOSPHATE DEPOSITS (HISTOCHEMICAL ASSAYS)

Calcium deposition appeared as red-orange spots when viewed under the inverted microscope. Figure 6(A) - 6(P) shows that the hFOB 1.19 cells treated with both fractions have a greater intensity of Alizarin Red $S$ staining compared to cells treated with pamidronate starting from day 3 of incubation period until day 10 . Interestingly, hFOB 1.19 cells treated with fraction B had the greatest intensity of calcium deposition at day 14 compared to the other three groups (Figure 6(Q) - 6(T)).

Besides that, phosphate deposition was identified by the presence of black spots from von Kossa staining when viewed under the inverted microscope. Starting from day 1 until day 14 , the amount of phosphate deposition increased in the cells treated with both semi-purified fractions of QI extract compared to the cells treated with pamidronate and untreated cells (Figure 7(A) - 7(T))

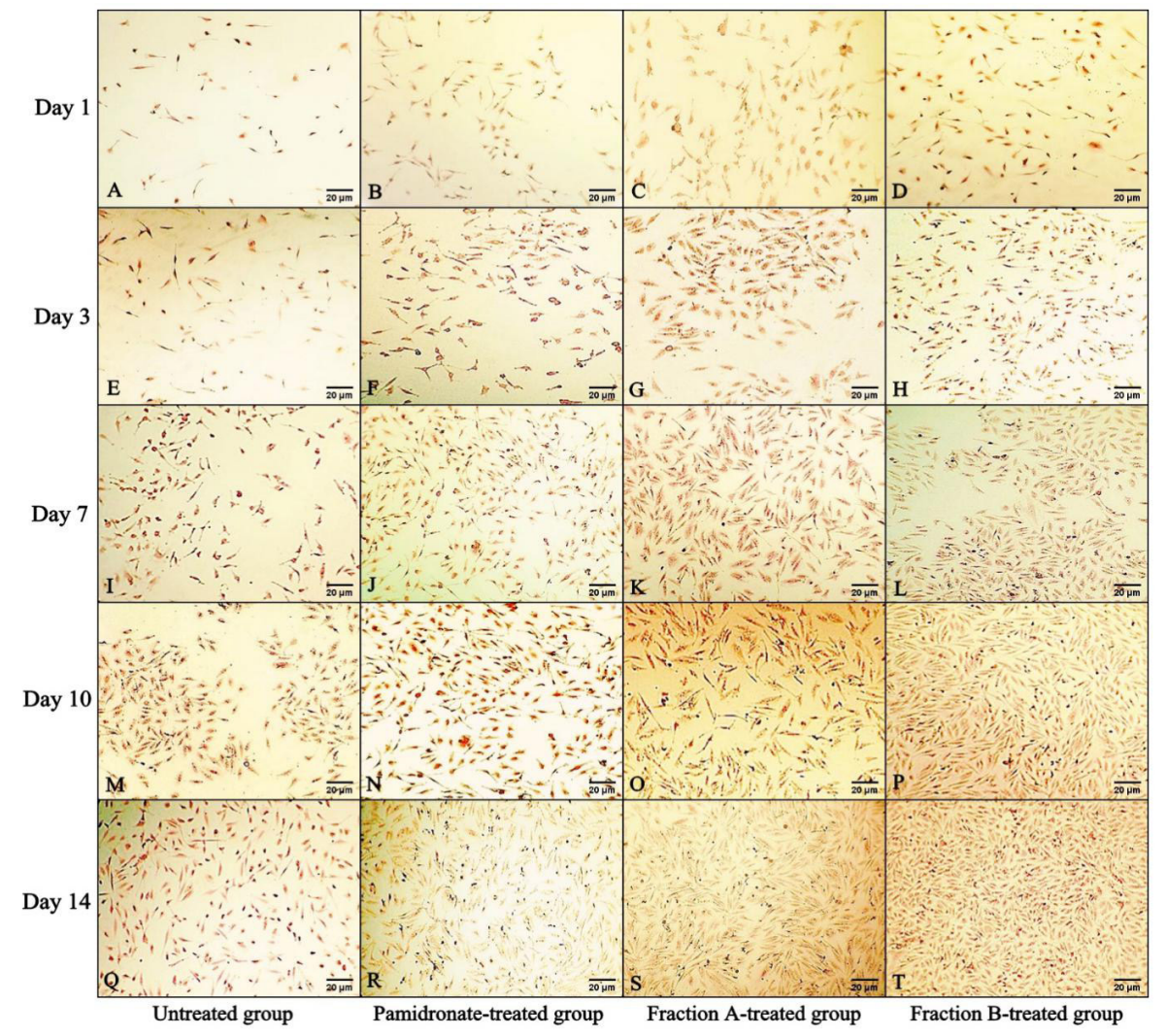

FIGURE 6. hFOB 1.19 cells after stained with Alizarin Red $S$ (calcium deposition) from day 1 until day 14, viewed at 20× magnification using an image analyser. (A) Day 1, untreated hFOB 1.19 cells, (B) Day 1, hFOB 1.19 cells treated with pamidronate, (C) Day 1, hFOB 1.19 cells treated with Fraction A, (D) Day 1, hFOB 1.19 cells treated with Fraction B, (E) Day 3, untreated hFOB 1.19 cells, (F) Day 3, hFOB 1.19 cells treated with pamidronate, (G) Day 3, hFOB 1.19 cells treated with Fraction A, (H) Day 3, hFOB 1.19 cells treated with Fraction B, (I) Day 7, untreated hFOB 1.19 cells, (J) Day 7, hFOB 1.19 cells treated with pamidronate, (K) Day 7, hFOB 1.19 cells treated with Fraction A, (L) Day 7, hFOB 1.19 cells treated with Fraction B, (M) Day 10, untreated hFOB 1.19 cells, (N) Day 10, hFOB 1.19 cells treated with pamidronate, (O) Day 10, hFOB 1.19 cells treated with Fraction A, (P) Day 10, hFOB 1.19 cells treated with Fraction B, (Q) Day 14, untreated hFOB 1.19 cells, (R) Day 14, hFOB 1.19 cells treated with pamidronate, (S) Day 14, hFOB 1.19 cells treated with Fraction A, (T) Day 14, hFOB 1.19 cells treated with Fraction B 


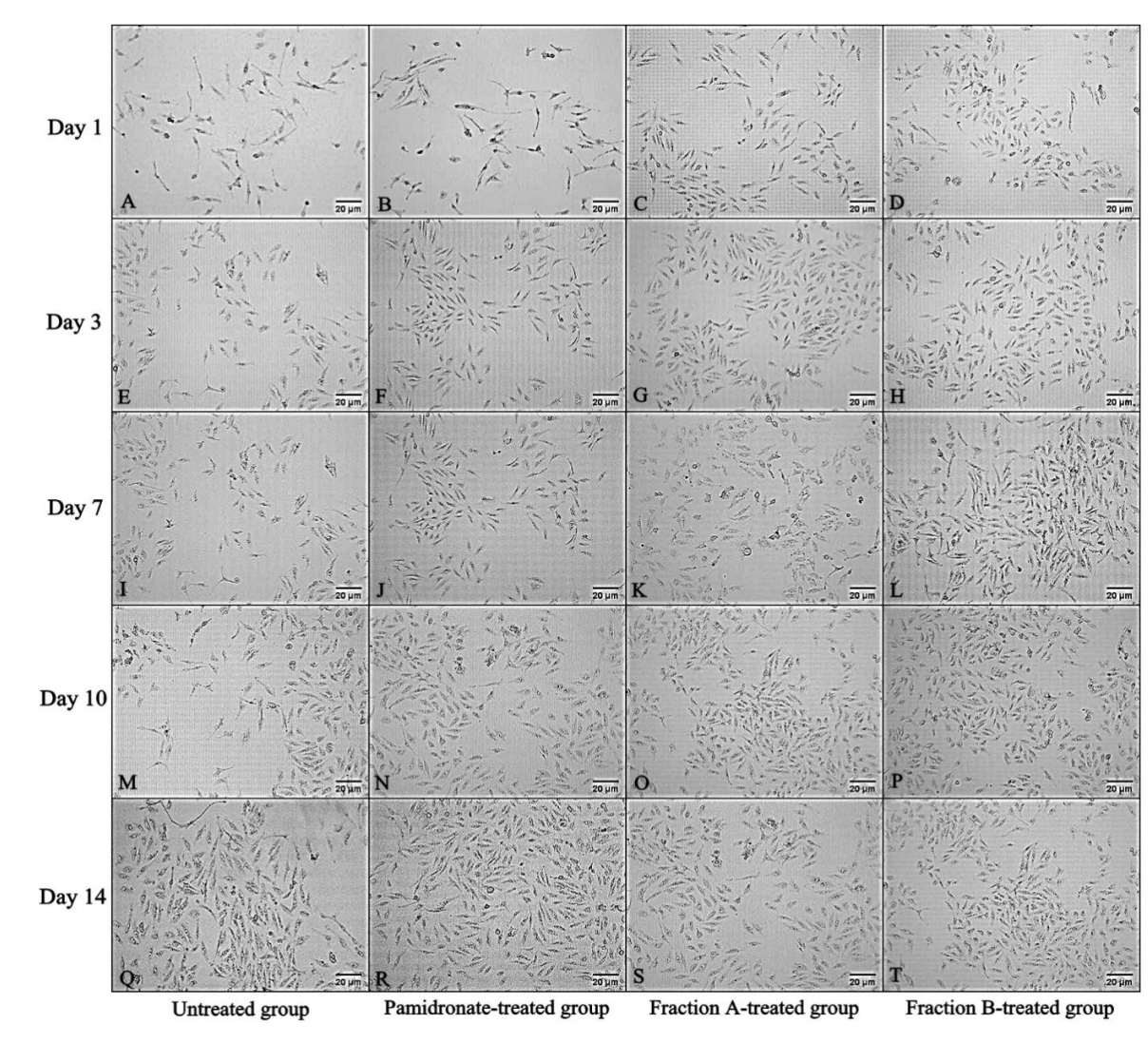

FIGURE 7. hFOB 1.19 cells stained with von Kossa (phosphate deposition) from day 1 until day 14 , viewed at $22 \times$ magnification using an inverted microscope. (A) Day 1, untreated hFOB 1.19 cells, (B) Day 1, hFOB 1.19 cells treated with pamidronate, (C) Day 1, hFOB 1.19 cells treated with Fraction A, (D) Day 1, hFOB 1.19 cells treated with Fraction B, (E) Day 3, untreated hFOB

1.19 cells, (F) Day 3, hFOB 1.19 cells treated with pamidronate, (G) Day 3, hFOB 1.19 cells treated with Fraction A, (H) Day 3, hFOB 1.19 cells treated with Fraction B, (I) Day 7, untreated hFOB 1.19 cells, (J) Day 7, hFOB 1.19 cells treated with pamidronate, (K) Day 7, hFOB 1.19 cells treated with Fraction A, (L) Day 7, hFOB 1.19 cells treated with Fraction B, (M) Day 10, untreated hFOB 1.19 cells, (N) Day 10, hFOB 1.19 cells treated with pamidronate, (O) Day 10, hFOB 1.19 cells treated with Fraction A, (P) Day 10, hFOB 1.19 cells treated with Fraction B, (Q) Day 14, untreated hFOB 1.19 cells, (R) Day 14, hFOB 1.19 cells treated with pamidronate, (S) Day 14, hFOB 1.19 cells treated with Fraction A, (T) Day 14, hFOB 1.19 cells treated with Fraction B

In this study, mineral deposition staining per viable hFOB 1.19 cells treated with fraction A and B increased at day 14 , in a time-dependent manner. This condition is in accordance with a previous study (Tong et al. 2007). Human embryonic stem cells (hESCs) formed bone nodules when co-cultured with human bone marrow mesenchymal stem cell (hBMSCs) that have differentiated for 14 days. The bone nodules stained positively for von Kossa and Alizarin Red S. Mineralised nodule formation is the hallmark of in vitro osteogenic differentiation. In contrast, cells grown with undifferentiated hBMSCs only showed minimal level of mineral deposition and weak staining (Tong et al. 2007).

Greater Alizarin Red $S$ and von Kossa staining indicate higher levels of mineral depositions (Tong et al. 2007). Therefore, semi-purified fractions of QI extract enhanced the mineralisation in hFOB 1.19 cells more effectively compared to pamidronate due to their high amount of calcium and phosphate deposition. In addition, formation of mineralised calcium and phosphate deposits 
in both cells treated with semi-purified fractions of QI extract were also observed and compared. Treatment with fraction B resulted in greater Alizarin Red S content, which indicates higher levels of mineral calcium compared to cells treated with fraction A.

von Kossa and Alizarin Red $S$ staining are widely used to detect calcification in skeletal tissues, and they are the standard methods to visualise mineralisation in osteogenic cell cultures (Bonewald et al. 2003). The von Kossa method is based on the binding of silver ions to the anions (phosphates, sulphates, or carbonates) of calcium salts and the reduction of silver salts to form dark brown or black metallic silver staining. Contrasting the nonspecificity of von Kossa for calcium, Alizarin Red $S$ reacts with calcium cation to form a chelate (Wang et al. 2006). Some pitfalls in von Kossa might be the reason we were unable to see the difference of mineral phosphate contents between the cells treated with fraction A and fraction B. To overcome the limitations of conventional histological von Kossa and Alizarin Red $S$ stain techniques as well as enable live analyses, fluorochrome-based labelling methods, such as Giemsa staining, have been proposed for the evaluation of bonelike nodule mineralisation in vitro (Querido et al. 2012).

The result of ALP activity is congruent with mineralisation activity. The ALP activity of cells treated with the fractions increased in a time-dependent manner; likewise, the mineral depositions were also augmented. This shows that there is a connection between ALP levels and mineral contents. To support this, a previous study had shown that resveratrol, a natural polyphenolic compound $\left(3,5,4^{\prime}\right.$-trihydroxy-trans-stilbene) present in fruits positively affected the bone, primarily by stimulating formation or mineralisation (Ornstrup et al. 2014). Next, Domazetovic et al. (2020) found that blueberry polyphenols protect from oxidative damage factors related to bone remodelling and bone formation, such as ALP and Runt-related transcription factor 2 (Runx2), and improve long-term activation of the mineralisation process in human osteoblast-like (SaOS-2) cells.

\section{CONCLUSION}

In conclusion, osteoblasts (hFOB 1.19 cells) treated with semi-purified fractions of QI extract were better in proliferation, ALP activity, and mineralisation compared to cells treated with pamidronate. Both semi-purified fractions (fractions A and B) enhanced bone metabolism with only a small effective concentration compared to pamidronate. Furthermore, the semi-purified fractions of QI extract also increased cell proliferation by increasing the level of bone formation markers (ALP) secreted by osteoblast cells. Moreover, the semi-purified fractions of QI extract also improved the mineralisation activity where they enhanced calcium and phosphate deposits of hFOB 1.19 cells.

\section{ACKNOWLEDGEMENTS}

The authors were grateful to the Ministry of Higher Education, Malaysia for funding this work under the Fundamental Research Grant Scheme (FRGS) [203/ PPSK/6171169]. We also thank the Biomedicine and Culture Laboratories of the School of Health Sciences, and Craniofacial Science Laboratory of the School of Dental Sciences, Universiti Sains Malaysia (USM) for the research facilities.

\section{REFERENCES}

Anand, T. \& Gokulakrishnan, K. 2012. Phytochemical analysis of Hybanthus enneaspermus using UV, FTIR and GC- MS IOSR Journal of Pharmacy 2(3): 520-524.

Asif, M., Ansari, S.H., Haque, M.R. \& Kalam, N. 2012. Standardization and contamination studies on nutgalls of Quercus infectoria Olivier. International Research Journal of Pharmacy 3(8): 149-152.

Avery, V.M., Camp, D., Carroll, A.R., Jenkins, I.D. \& Quinn, R.J. 2010. The Identification of Bioactive Natural Products by High Throughput Screening (HTS): Comprehensive Natural Products II Chemistry and Biology. 1st vol. United Kingdom: Elsevier.

Aysal, P., Ambrus, A.D., Lehotay, S.J. \& Cannavan, A. 2007. Validation of an efficient method for the determination of pesticide residues in fruits and vegetables using ethyl acetate for extraction. Journal of Environmental Science and Health, Part B 42(5): 481-490.

Bonewald, L.F., Harris, S.E., Rosser, J., Dallas, M.R., Dallas, S.L., Camacho, N.P., Boyan, B. \& Boskey, A. 2003. von Kossa staining alone is not sufficient to confirm that mineralization in vitro represents bone formation. Calcified Tissue International 72(5): 537-547.

Bruneton, J. 1999. Pharmacognosy: Phyochemistry, Medicinal Plants. Hampshire: Lavoisier Publication.

Bu, S.Y., Hunt, T.S. \& Smith, B.J. 2009. Dried plum polyphenols attenuate the detrimental effects of TNF-a on osteoblast function coincident with up-regulation of Runx2, Osterix and IGF-I. The Journal of Nutritional Biochemistry 20(1): $35-44$.

Dai, Z., Li, Y., Quarles, L.D., Song, T., Pan, W., Zhou, H. \& Xiao, Z. 2007. Resveratrol enhances proliferation and osteoblastic differentiation in human mesenchymal stem cells via ER-dependent ERK1/2 activation. Phytomedicine 14(12): 806-814

Davidson, M.R. 2003. Pharmacotherapeutics for osteoporosis prevention and treatment. Journal of Midwifery Women's Health 48(1): 139-152. 
Domazetovic, V., Marcucci, G., Falsetti, I., Bilia, A.R., Vincenzini, M.T., Brandi, M.L. \& Iantomasi, T. 2020. Blueberry juice antioxidants protect osteogenic activity against oxidative stress and improve long-term activation of the mineralization process in human osteoblast-like SaOS-2 cells: Involvement of SIRT1. Antioxidants (Basel) 9(2): 125-144

Eberhardt, T.L., Li, X., Shupe, T.F. \& Hse, C.Y. 2007. Chinese Tallow Tree (Sapium sebiferum) utilization: Characterization of extractives and cell-wall chemistry. Wood and Fiber Science 39(2): 319-324.

Fantini, M., Benvenuto, M., Masuelli, L., Frajese, G.V., Tresoldi, I., Modesti, A. \& Bei, R. 2015. In vitro and in vivo antitumoral effects of combinations of polyphenols, or polyphenols and anticancer drug: perspectives on cancer treatment. International Journal of Molecular Science 16(5): 9236-9282.

Garcia-Martinez, O., De Luna-Bertos, E., Ramos-Torrecillas, J., Ruiz, C., Milia, E., Lorenzo, M.L., Jimenez, B., Sanchez-Ortiz, A. \& Rivas, A. 2016. Phenolic compounds in extra virgin olive oil stimulate human osteoblastic cell proliferation. PLoS ONE 11(3): e0150045.

Gundberg, C.M. 1993. Alkaline Phosphatase and Osteocalcin: Primer on the Metabolic Bone Diseases and Disorders of Mineral Metabolism. American Society of New York: Bone and Mineral Research.

Habauzit, V. \& Horcajada, M.N. 2008. Phenolic phytochemicals and bone. Phytochemistry Review 7: 313344.

Hapidin, H., Rozelan, D., Abdullah, H., Wan Hanaffi, W.N. \& Soelaiman, I.N. 2015. Quercus infectoria gall extract enhanced the proliferation and activity of human fetal osteoblast cell line (hFOB 1.19). The Malaysian Journal of Medical Sciences 22(1): 12-22.

Hassan, M.A.K., Azeminb, W.A., Dharmaraja, S. \& Mohd, K.S. 2015. Cytotoxic effect of hepcidin (TH1-5) on human breast cancer cell line (MCF7). Jurnal Teknologi 77(3): 73-79.

Hazra, K.M., Roy, R.N., Sen, S.K. \& Laska, S. 2007. Isolation of antibacterial pentahydroxy flavones from the seeds of Mimusops elengi Linn. African Journal of Biotechnology 6(18): 1446-1449.

Humphries, K.H. \& Sabrina Gill, S. 2003. Risks and benefits of hormone replacement therapy: The evidence speaks. CMAJ 168(8): 1001-1010.

Hurst, R.D., Wells, R.W., Hurst, S.M., McGhie, T.K., Cooney, J.M. \& Jensen, D.J. 2010. Blueberry fruit polyphenolics suppress oxidative stress-induced skeletal muscle cell damage in vitro. Molecular Nutrition \& Food Research 54(3): 353-363.

Ibrahim, M. \& Abd-El-Aal, M. 2008. Spectroscopic study of the interaction of heavy metals with organic acids. International Journal of Environment and Pollution 35(1): 99-110.

Idris, A.I., Greig, I.R., Bassonga-Landao, E., Ralston, S.H. \& van't Hof, R.J. 2009. Identification of novel biphenyl carboxylic acid derivatives as novel antiresorptive agents that do not impair parathyroid hormone-induced bone formation. Endocrinology 150(1): 5-13.
Kowalczyk, R., Brimble, M.A., Callon, K.E., Watson, M. \& Cornish, J. 2010. How to blast osteoblasts? Novel dicarba analogues of amylin (1-8) to treat osteoporosis. Bioorganic \& Medicinal Chemistry 20(20): 6011-6018.

Li, Z., Zhou, Z., Saunders, M.M. \& Donahue, H.J. 2006. Modulation of connexin43 alters expression of osteoblastic differentiation markers. American Journal of Physiology Cell Physiology 290(4): C1248-C1255.

Liebler, D.C., Burr, J.A. \& Ham, A.J. 1999. Gas chromatographymass spectrometry analysis of vitamin $\mathrm{E}$ and its oxidation products. Methods in Enzymology 299: 309-318.

Mar, C. \& Bent, S. 1999. An evidence-based review of the 10 most commonly used herbs. The Western Journal of Medicine 171(3): 168-171.

McGEE-Russell, S.M. 1958. Histochemical methods for calcium. Journal of Histochemistry and Cytochemistry 6(1): 22-42.

Muhamad, Z. \& Mustafa, A.M. 1994. Traditional Malay Medicinal Plants. Kuala Lumpur: Penerbit Fajar Bakti Sdn Bhd.

Naz, S., Khaskheli, A.R., Aljabour, A., Kara, H., Talpur, F.N., Sherazi, S.T.H., Khaskheli, A.A\& Jawaid, S. 2014. Synthesis of highly stable cobalt nanomaterial using gallic acid and its application in catalysis. Advances in Chemistry 2014: Article ID. 686925.

Noe, V., Penuelas, S., Lamuela-Raventos, R.M., Permanyer, J., Ciudad, C.J. \& Izquierdo-Pulido, M. 2004. Epicatechin and a cocoa polyphenolic extract modulate gene expression in human Caco-2 cells. The Journal of Nutrition 134(10): 2509-2516.

Ornstrup, M.J., Harsløf, T., Kjær, T.N., Langdahl, B.L. \& Pedersen, S.B. 2014. Resveratrol increases bone mineral density and bone alkaline phosphatase in obese men: A randomized placebo-controlled trial. The Journal of Clinical Endocrinology Metabolism 99(12): 4720-4729.

O’Prey, J., Brown, J., Fleming, J. \& Harrison, P.R. 2003. Effects of dietary flavonoid on major signal transduction pathway in human epithelial cells. Biochemical Pharmacology 66(11): 2075-2088.

Pantoja-Castro, M.A. \& Gonzalez-Rodriguez, H. 2012. Study by infrared spectroscopy and thermogravimetric analysis of tannins and tannic acid. Revista Latinoamericana de Química 39(3): 107-112.

Putnam, S.E., Scutt, A.M., Bicknell, K., Priestley, C.M. \& Williamson, E.M. 2007. Review article: Natural products as an alternative treatment for metabolic bone disorders and for maintenance of bone health. Phytotherapy Research 21(2): 99-112.

Querido, W., Farina, M. \& Balduino, A. 2012. Giemsa as a fluorescent dye for mineralizing bone-like nodules in vitro. Biomedical Materials 7(1): 011001.

Raudhah, A.A., Hermizi, H. \& Abdullah, H. 2018. Combination treatment of bisphosphonate (pamidronate) and Quercus infectoria semi-purified fraction promote proliferation and differentiation of osteoblast cell via expression of Osterix and Runx2 marker. Asian Pacific Journal of Tropical Biomedicine 8(5): 261-267. 
Sasidharan, S., Chen, Y., Saravanan, D., Sundram, K.M. \& Yoga Latha, L.Y. 2011. Extraction, isolation and characterization of bioactive compounds from plants' extracts. African Journal of Traditional Complementary Alternative Medicines 8(1): $1-10$.

Sözen, T., Özış1k, L. \& Başaran, N.C. 2017. An overview and management of osteoporosis. European Journal of Rheumatology 4(1): 46-56.

Sreekumar, S., Sithul, H., Muraleedharan, P., Mohammed Azeez, J. \& Sreeharshan, S. 2014. Pomegranate fruit as a rich source of biologically active compounds. BioMed Research International 2014: Article ID. 686921.

Stipanuk, M.H. \& Caudill, M.A. 2013. Pomegranate Fruit as a Rich Source of Biologically Active Compounds. United States: Elsevier Saunders.

Tong, W., Brown, S.E. \& Krebsbach, P.H. 2007. Human embryonic stem cells undergo osteogenic differentiation in human bone marrow stromal cell microenvironments. Journal of Stem Cells 2(3): 139-147.

Trzeciakiewicz, A., Habauzit, V. \& Hocajada, M.N. 2009. When nutrition interacts with osteoblast function: Molecular mechanisms of polyphenols. Nutrition Research Reviews 22(1): 68-81.

Tsao, R. 2010. Chemistry and biochemistry of dietary polyphenols. Nutrients 2(12): 12311246.

Vester, H., Holzer, N., Neumaier, M., Lilianna, S., Nussler, A.K. \& Seeliger, C. 2014. Green Tea Extract (GTE) improves differentiation in human osteoblasts dueing oxidative stress. Journal of Inflammation (Lond). 11: 15.

Vignesh, S., Ishita, B., Pranav, R. \& Rajendran, N. 2015. Phytochemical screening and functional group analysis of four medicinally important plants. Journal of Chemical and Pharmaceutical Research 7(1): 116-123.
Vittal, R., Selvanayagam, Z.E., Sun, Y., Hong, J., Lui, F., Chin, K.V. \& Yang, C.S. 2004. Gene expresion changes induced by green tea polyphenol (2)-epigallocatechin 3-gallate in human bronchial epithelial 21BES cells analysed by DNA microarray. Molecular Cancer Therapeutics 3(9): 1091-1099.

Wang, Y.H., Liu, Y., Maye, P. \& Rowe, D.W. 2006. Examination of mineralized nodule formation in living osteoblastic cultures using fluorescent dyes. Biotechnology Progress 22(6): 1697-1701.

Yamunadevi, M., Wesely, E.G. \& Johnson, M. 2012. FTIR spectroscopic studies on Aerva lanata (L.) Juss. ex Schult. Asian Journal of Pharmaceutical Clinical Research 5(2): 82-86.

Zhou, Y., Beyene, D., Zhang, R., Kassa, A., Ashayeri, E. \& Sridhar, R. 2008. Cytotoxicity of etidronic acid to human breast cancer cells. Ethnicity \& Disease 18(2 Suppl 2): 87-92.

Hermizi Hapidin*, Fairuza Munirah Mazlan \& Hasmah Abdullah Biomedicine Programme, School of Health Sciences

Universiti Sains Malaysia, Health Campus

16150 Kubang Kerian, Kelantan Darul Naim

Malaysia

Ima Nirwana Soelaiman

Department of Pharmacology

Universiti Kebangsaan Malaysia Medical Centre

Jalan Yaacob Latif, Bandar Tun Razak

56000 Cheras, Kuala Lumpur

Malaysia

*Corresponding author; email: hermizi@usm.my

Received: 14 April 2020

Accepted: 5 August 2020 